\title{
ANALISA CAPAIAN BELAJAR PADA MATA PELAJARAN BAHASA INGGRIS MELALUI KOMPETENSI GURU KELAS
}

\author{
Endang Iryani \\ Pendidikan Bahasa Inggris, Universitas MH Thamrin \\ endang1084@gmail.com
}

\begin{abstract}
Abstrak
Fenomena manajemen tentang guru kelas di sekolah dasar (SD/MI) yang mengajar semua mata pelajaran masih terjadi di Indonsia, salah satunya adalah di Tangerang Selatan. Guru mengajar mata pelajaran diluar kompetensi profesionalnya seperti mata pelajaran Bahasa Inggris diampu oleh guru yang bukan sarjana Bahasa Inggris. Penelitian ini bertujuan mengetahui hubungan kemampuan guru kelas dalam mengajar terhadap prestasi belajar siswa pada pelajaran Bahasa Inggris di MI Mifathul Huda Cipayung. Hipotesis yang diuji adalah: (1) korelasi positif antara kompetensi guru kelas dengan prestasi belajar siswa pada mata pelajaran Bahasa Inggris; (2) tidak terdapat korelasi kompetensi guru terhadap prestasi belajar siswa. Metode penelitian yang digunakan adalah kuantitatif dengan pendekatan survei. Sampel berjumlah 43 guru dari populasi. Hasil penelitian menunjukkan: kontribusi kompetensi guru kelas berhubungan positif secara signifikan pada prestasi belajar siswa. Sehingga dapat disimpulkan bahwa terdapat korelasi positif antara kompetensi guru terjadi secara tidak langsung melalui prestasi belajar siswa.
\end{abstract}

Kata kunci: kompetensi guru; prestasi; Bahasa Inggris

\section{PENDAHULUAN}

Fungsi dan Tujuan pendidikan nasional berdasarkan Undang-undang nomor 20 tahun 2003 Bab II pasal 3 adalah Pendidikan nasional dapat mengembangkan kemampuan dan membentuk watak serta peradaban bangsa yang bermartabat dalam rangka mencerdaskan kehidupan bangsa, bertujuan untuk berkembangnya potensi peserta didik agar menjadi manusia yang beriman dan bertakwa kepada Tuhan Yang Maha Esa, berakhlak mulia, sehat, berilmu, cakap, kreatif, mandiri, dan menjadi warga negara yang demokratis serta bertanggung jawab. Menginjak fungsi pendidikan pada UU nomor 20 tahun 2003 ini, bahwa sekolah sebagai lembaga pendidikan menjadi penopang akan pembangunan manusia Indonesia yang berujung pada kemakmuran bangsa. Karena sekolah merupakan lembaga pendidikan yang menjadi pabrik dalam mengolah generasi penerus menjadi manusia Indonesia yang cerdas dalam sikap dan karakter seperti amanat UU nomor 20 tahun 2003.

Tentunya, menciptakan atau mendidik manusia Indonesia tidaklah mudah, yang mana sekolah harus memiliki kurikulum dan Sumber Daya Manusia (SDM) yang handal. Karena keberhasilan sekolah tidak hanya didukung oleh Kurikulum 
Research and Development Journal Of Education

Vol. 6 No. 1 Oktober 2019

p-ISSN 2406-9744

e-ISSN 2657-1056

yang bagus tapi juga bagaimana seorang guru memiliki kompetensi dalam pengetahuan dan tehnik mengajar agar siswa bisa mendapatkan pengetahuan yang diharapkan dan tujuan pendidikan bisa tercapai (Sumar, 2016). Hal ini bisa dilihat dari beberapa hasil penellitian yang dilakukan oleh akademisi yang memandang bahwa kompetensi guru sangatlah penting terhadap dunia pendidikan. Sebagaimana para peneliti melakukan kajian akan kompetensi guru terhadap pendidikan, seperti Cut Fitriani dengan judul penelitiannya Kompetensi Profesional Guru Dalam Pengelolaan Pembelajaran di MTS Muhammadiyah Banda Aceh menunjukan bahwa guru yang tidak memiliki profesionalitas dan kemampuan dalam menyusun perencanaan pembelajaran sesuai dengan kurikulum menjadikan pendidikan di MTS Muhamadiyah Banda Aceh berjalan tidak baik (Cut Fitriani, 2017). Begitu juga dengan Indah Susilowati yang melakukan penelitian dengan judul Strategi Peningkatan Kompetensi Guru Dengan Pendekatan Analysis Hierarchy Process, dalam penelitianya menghasilkan bahwa kompetensi pedagogik dan kompetensi profesional guru adalah moderat dan guru memiliki kepribadian dan kompetensi sosial yang tinggi. Hal yang harus ditingkatkan adalah kompetensi guru (Indah Susilowati, 2013).

Dari dua penelitian tersebut dapat digambarkan bahwa kedudukan kompetensi guru sangatlah penting dalam menopang keberhasilan belajar siswa. Karena kompetensi guru ini tidak hanya meliputi dalam kemampuan pengetahuan saja (profesional) akan tetapi menyangkut kepribadian seperti ketaatan terhadap Tuhan Yang Maha Esa, mengembangkan sifat-sifat terpuji yang bisa dicontoh oleh siswa juga dalam kemampuan komunikasi, baik terhadap siswa ataupun masyarakat sekolah lainya (Anwar, 2018). Sehingga bisa dikatakan bahwa keberhasilan pembelajaran baik dari tingkat MI/SD, MTS/SMP dan MA/SMA sangat dipengaruhi oleh kompetensi guru selaku aplikator dari kurikulum.

Kompetensi profesional guru bisa didapatkan dari proses pendidikan guru diperguruan tinggi. Dengan manajemen pemerintah menyediakan berbagai macam program studi (PRODI) yang bisa diambil oleh calon guru ketika mereka belajar. Mampu ditemukan ada berbagai macam jenis PRODI pendidikan yang bisa diambil oleh calon-calon pendidikan (guru) seperti, PGSD, PAUD, Pendidikan Bahasa Inggris, Pendidikan Fisika dan sebagainya. Sehingga bisa disimpulkan bahwa pada dasarnya guru-guru di Indonesia memiliki kompetensi profesional 
Research and Development Journal Of Education

Vol. 6 No. 1 Oktober 2019

p-ISSN 2406-9744

e-ISSN 2657-1056

yang telah mereka tempuh selama belajar diperguruan tinggi. Artinya guru-guru di Indonesia telah memiliki kompetensi profesional secara keseluruhan.

Akan tetapi, fenomena pendidikan ditingkat Sekolah Dasar (SD/MI) terjadi penempatan pengajaran mata pelajaran yang diampu oleh guru yang tidak linear dalam kompetensi profesionalnya. Di Sekolah Dasar masih terdapat manajemen guru kelas, yakni guru yang mengajar untuk semua mata pelajaran. Hal ini terjadi disekolah-sekolah dasar dan setingkatnya seperti Madrasah Ibtidaiyah (MI), guruguru kelas yang kompetensi profesionalnya hanya satu keahlian seperti, PGSD, atau pendidikan IPS tapi mereka melakukan pengajaran pada siswa untuk semua pelajaran termasuk Bahasa Inggris.

Hal inilah yang kemudian menjadi ketertarikan bagi peneliti untuk melakukan analisa terhadap kompetensi profesional guru pada capaian pembelajaran Bahasa Inggris. peneliti melihat ada beberapa sekolah di Tangerang Selatan pada tingkat sekolah dasar masih menggunakan manajemen guru kelas dalam melaksanakan pengajaran, salah satunya adalah Madrasah Ibtidaiyah (MI) Miftahul Huda Cipayung Ciputat Tangerang Selatan. Sekolah yang paling tua untuk tingkat MI di Ciputat, dan memiliki jumlah siswa setiap tahunya tidak kurang dari 60 siswa baru yang mendaptar. Sedangkan pengambilan mata pelajaran Bahasa Inggris karena pada MI Miftahul Huda tidak ada guru tetap yang backgroundnya pendidikan Bahasa Inggris. sehingga hal ini memiliki fenomena menarik bagi peneliti untuk melihat bagaimana capaian belajar siswa pada mata pelajaran Bahasa Inggris. karena Bahasa Inggris sampai saat ini masih dianggap susah oleh beberapa siswa dan masih terdapat permasalahan dalam metode pengajaran Bahasa Inggris, seperti hasil penelitian dari Sjafty Nursitti Maili dan Woro Hestiningsih dengan judul Masalah-Masalah Pembelajaran Bahasa Inggris Pada Sekolah Dasar, hasil penelitiannya menunjukan bahwa Pertama metode dan modelpembelajaran Bahasa Inggris perlu ditingkatkan; Kedua Sekolah perlu mendukung pembelajaran Bahasa Inggris pada sekolah dasar; Ketiga, Bahasa Inggris dibutuhkan dalam pembelajaran pada sekolah dasar (Hestiningsih, 2016). Berlandaskan dari latar belakang itu semua, tujuan dari penelitian ini untuk mengetahui sejauhmana kompetensi guru kelas memiliki pengaruh dalam capaian belajar siswa, dan apakah terdapat hubungan antara kompetensi guru kelas dengan capaian belajar siswa. 
Research and Development Journal Of Education

Vol. 6 No. 1 Oktober 2019

p-ISSN 2406-9744

e-ISSN 2657-1056

\section{METODE}

Metode penelitian ini adalah kualitatif dengan pendekatan Survey. Penelitian dilaksanakan pada bulan Agustus sampai dengan Oktober 2018, dengan jumlah sample 43 dari jumlah populasi. Data dianalisis dengan statistik deskriptif dan inferensial. Statsistik deskriptif digunakan untuk kecenderungan pemusatan data (mean), kecenderungan penyebaran data (simpang baku), serta pembuatan tabel frekuensi dalam bentuk diagram batang dan daun. Statistik inferensial digunakan untuk pengujian hipotesis penelitian dengan menggunakan korelasi produk momen. Pengujian signifikansi koefisien korelasi dengan membandingkan probability-valuenya dengan taraf signifikansi 0,05 pada uji satu sisi. Hipotesis nol ditolak apabila valuenya lebih kecil dari taraf signifikansi tersebut. Dengan kerangka penelitian sebagai berikut:

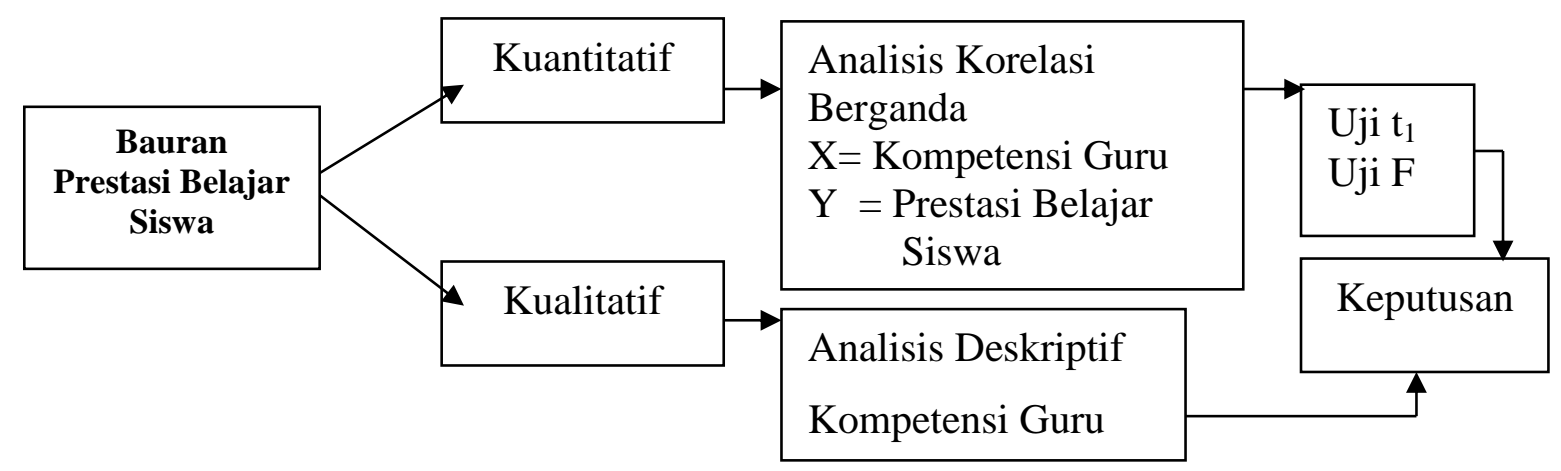

\section{HASIL DAN PEMBAHASAN}

Deskripsi dari penelitian ini adalah penelitian dilakukan agar secara jelas dapat diperoleh gambaran atas pernyataan dari para responden terhadap variabelvariabel yang tercakup dalam penelitian ini, yaitu hubungan kompetensi guru dengan prestasi belajar siswa pada mata pelajaran Bahasa Inggris di Madrasah Ibtidaiyah (MI) Miftahul Huda Cipayung Ciputat Tangerang Selatan.

a. Distribusi frekuensi variabel kompetensi guru

Dari pernyataan-pernyataan yang dibuat oleh para responden pada angket yang diberikan kepadanya terhadap kompetensi guru persentase pertanyaan sebagai berikut :

- $(40,31 \%)$ responden menyatakan sangat setuju 260

- $(39,53 \%)$ responden menyatakan setuju 255

- $(12,24 \%)$ responden menyatakan kurang setuju 79

- $(9,03 \%)$ responden menyatakan tidak setuju 42

- $(1,39 \%)$ responden menyatakan sangat tidak setuju 9 
Research and Development Journal Of Education

Vol. 6 No. 1 Oktober 2019

p-ISSN 2406-9744

e-ISSN 2657-1056

Berdasarkan angka-angka tersebut diatas dapat disimpulkan bahwa sebagian besar responden sangat setuju dan setuju dengan kompetensi guru dalam meningkatkan prestasi belajar siswa. Untuk lebih jelasnya dapat dilihat pada tabel dibawah ini.

Tabel 1. Frekuensi Skor Penilaian dan \% Pernyataan Responden Terhadap Variabel Kompetensi guru (X)

\begin{tabular}{|c|c|c|c|c|c|c|}
\hline \multirow{2}{*}{ PERTANYAAN } & \multicolumn{5}{|c|}{ SKOR PENILAIAN DAN \% PERTANYAAN } \\
\cline { 2 - 7 } & STS & TS & KS & S & SS & Total \\
\hline Kompetensi guru 1 & 0 & 4 & 0 & 13 & 26 & 43 \\
\hline Kompetensi guru 2 & 0 & 0 & 5 & 19 & 19 & 43 \\
\hline Kompetensi guru 3 & 0 & 1 & 2 & 17 & 23 & 43 \\
\hline Kompetensi guru 4 & 2 & 13 & 5 & 12 & 11 & 43 \\
\hline Kompetensi guru 5 & 1 & 0 & 3 & 21 & 18 & 43 \\
\hline Kompetensi guru 6 & 0 & 0 & 4 & 16 & 23 & 43 \\
\hline Kompetensi guru 7 & 1 & 2 & 2 & 18 & 20 & 43 \\
\hline Kompetensi guru 8 & 0 & 1 & 5 & 17 & 20 & 43 \\
\hline Kompetensi guru 9 & 2 & 2 & 5 & 19 & 15 & 43 \\
\hline Kompetensi guru 10 & 0 & 5 & 9 & 14 & 15 & 43 \\
\hline Kompetensi guru 11 & 0 & 3 & 13 & 23 & 4 & 43 \\
\hline Kompetensi guru 12 & 0 & 1 & 8 & 17 & 17 & 43 \\
\hline Kompetensi guru 13 & 2 & 6 & 15 & 14 & 6 & 43 \\
\hline Kompetensi guru 14 & 0 & 3 & 0 & 17 & 23 & 43 \\
\hline Kompetensi guru 15 & 1 & 1 & 3 & 18 & 20 & 43 \\
\hline Kompetensi guru & 9 & 42 & 79 & 255 & 260 & 645 \\
\hline \% & 1,39 & 9,03 & 12,24 & 39,53 & 40,31 & 100 \\
\hline
\end{tabular}

Sumber: data olahan

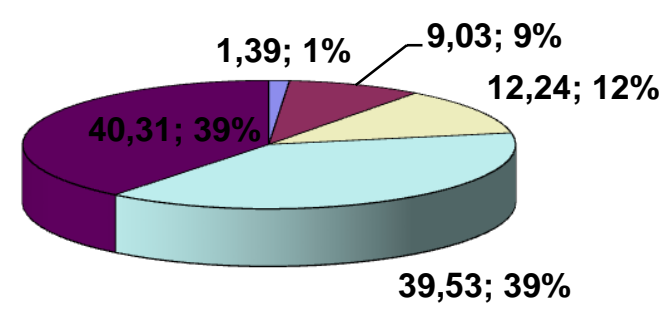

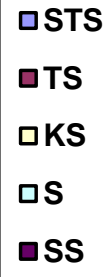

aSS

Gambar 1. Frekuensi Pernyataan Responden Terhadap Variabel Kompetensi Guru

b. Distribusi frekuensi variabel prestasi belajar siswa

Dari pernyataan-pernyataan yang dibuat oleh para responden pada angket yang diberikan kepadanya terhadap prestasi belajar siswa menunjukkan persentase pertanyaan sebagai berikut :

- $(39,54 \%)$ responden menyatakan sangat setuju 260

- $(39,53 \%)$ responden menyatakan setuju 255 
Research and Development Journal Of Education

Vol. 6 No. 1 Oktober 2019

p-ISSN 2406-9744

e-ISSN 2657-1056

- $(12,24 \%)$ responden menyatakan kurang setuju 79

- $(9,03 \%)$ responden menyatakan tidak setuju 42

- $(1,39 \%)$ responden menyatakan sangat tidak setuju 9

Berdasarkan angka-angka tersebut diatas dapat disimpulkan bahwa sebagian besar responden setuju dan sangat setuju dengan kompetensi guru dalam meningkatkan prestasi belajar siswa.

Tabel 2. Frekuensi Skor Penilaian dan \% Pertanyataan Responden Terhadap Variabel Prestasi belajar siswa (Y)

\begin{tabular}{|l|c|c|c|c|c|c|}
\hline \multirow{2}{*}{} & \multicolumn{7}{|c|}{ PERTANYAAN } & \multicolumn{1}{l|}{} \\
\cline { 2 - 7 } & STS & TS & KS & S & SS & Total \\
\hline Prestasi belajar siswa. 1 & 1 & 0 & 5 & 18 & 19 & 43 \\
\hline Prestasi belajar siswa 2 & 3 & 2 & 5 & 14 & 19 & 43 \\
\hline Prestasi belajar siswa.3 & 0 & 3 & 2 & 21 & 17 & 43 \\
\hline Prestasi belajar siswa.4 & 0 & 2 & 9 & 20 & 12 & 43 \\
\hline Prestasi belajar siswa.5 & 0 & 1 & 4 & 22 & 16 & 43 \\
\hline Prestasi belajar siswa.6 & 0 & 6 & 4 & 21 & 12 & 43 \\
\hline Prestasi belajar siswa.7 & 0 & 1 & 2 & 22 & 18 & 43 \\
\hline Prestasi belajar siswa.8 & 0 & 0 & 2 & 15 & 26 & 43 \\
\hline Prestasi belajar siswa.9 & 0 & 2 & 2 & 21 & 18 & 43 \\
\hline Prestasi belajar siswa. 10 & 0 & 1 & 3 & 15 & 24 & 43 \\
\hline Prestasi belajar siswa.11 & 0 & 0 & 4 & 22 & 17 & 43 \\
\hline Prestasi belajar siswa.12 & 0 & 0 & 7 & 21 & 15 & 43 \\
\hline Prestasi belajar siswa.13 & 0 & 3 & 4 & 18 & 18 & 43 \\
\hline Prestasi belajar siswa.14 & 0 & 1 & 7 & 23 & 12 & 43 \\
\hline Prestasi belajar siswa.15 & 0 & 0 & 5 & 20 & 18 & 43 \\
\hline Prestasi belajar siswa.. & 4 & 22 & 65 & 293 & 261 & 645 \\
\hline \% & 0,62 & 3,41 & 10,07 & 45,42 & 40,46 & 100 \\
\hline
\end{tabular}

Sumber : Data Olahan

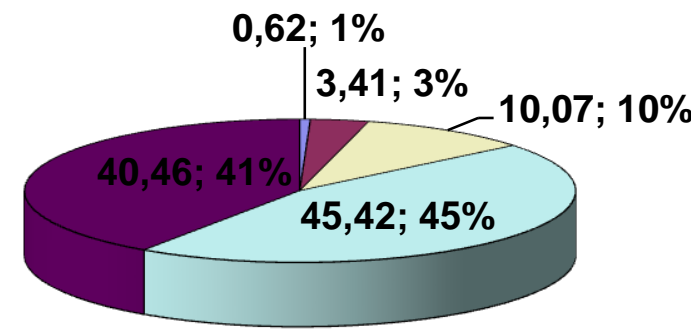

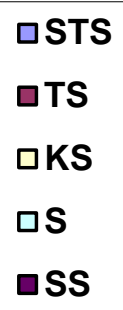

Gambar 2. Frekuensi Responden Pernyataan Prestasi Belajar Siswa 
Research and Development Journal Of Education

Vol. 6 No. 1 Oktober 2019

\section{Pengujian Persyaratan Analisis}

\section{Pengujian Validitas Instrumen}

Hasil pengujian validitas terhadap 15 item instrumen kompetensi guru diperoleh 15 item yang koefisien korelasinya dinyatakan valid. Maka 15 item tersebut digunakan untuk instrumen penelitian seperti dalam tabel berikut :

Tabel 3. Rekapitulasi Nilai r Untuk Uji Validitas Instrument Penelitian Variabel Kompetensi guru (X)

\begin{tabular}{|c|c|c|c|}
\hline $\begin{array}{c}\text { Nomor } \\
\text { Kuesioner }\end{array}$ & r-butir & r-tabel & Keterangan \\
\hline X.1 & 0,538 & 0,301 & Valid \\
\hline X.2 & 0,629 & 0,301 & Valid \\
\hline X.3 & 0,706 & 0,301 & Valid \\
\hline X.4 & 0,637 & 0,301 & Valid \\
\hline X.5 & 0,665 & 0,301 & Valid \\
\hline X.6 & 0,463 & 0,301 & Valid \\
\hline X.7 & 0,781 & 0,301 & Valid \\
\hline X.8 & 0,746 & 0,301 & Valid \\
\hline X.9 & 0,515 & 0,301 & Valid \\
\hline X.10 & 0,679 & 0,301 & Valid \\
\hline X.11 & 0,595 & 0,301 & Valid \\
\hline X.12 & 0,400 & 0,301 & Valid \\
\hline X.13 & 0,441 & 0,301 & Valid \\
\hline X.14 & 0,452 & 0,301 & Valid \\
\hline X.15 & 0,503 & 0,301 & Valid \\
\hline
\end{tabular}

Sumber : Data Olahan

Selanjutnya hasil uji validitas 15 item instrumen variabel prestasi belajar siswa ternyata diperoleh 15 item yang koefisien korelasinya dinyatakan valid. Maka item ini digunakan untuk instrumen penelitian seperti tabel berikut :

Tabel 4. Rekapitulasi Nilai r Untuk Uji Validitas Instrument Penelitian Variabel Prestasi belajar siswa (Y)

\begin{tabular}{|c|c|c|c|}
\hline $\begin{array}{c}\text { Nomor } \\
\text { Kuesioner }\end{array}$ & r-butir & r-tabel & Keterangan \\
\hline Y.1 & 0,606 & 0,301 & Valid \\
\hline Y.2 & 0,651 & 0,301 & Valid \\
\hline Y.3 & 0,745 & 0,301 & Valid \\
\hline Y.4 & 0,568 & 0,301 & Valid \\
\hline Y.5 & 0,559 & 0,301 & Valid \\
\hline Y.6 & 0,420 & 0,301 & Valid \\
\hline Y.7 & 0,688 & 0,301 & Valid \\
\hline Y.8 & 0,506 & 0,301 & Valid \\
\hline Y.9 & 0,773 & 0,301 & Valid \\
\hline Y.10 & 0,367 & 0,301 & Valid \\
\hline Y.11 & 0,779 & 0,301 & Valid \\
\hline Y.12 & 0,421 & 0,301 & Valid \\
\hline Y.13 & 0,623 & 0,301 & Valid \\
\hline Y.14 & 0,380 & 0,301 & Valid \\
\hline Y.15 & 0,498 & 0,301 & \\
\hline
\end{tabular}

Sumber : Data Olahan 
Research and Development Journal Of Education

Vol. 6 No. 1 Oktober 2019

\section{Pengujian Reliabilitas Instrumen}

Melalui penghitungan dengan bantuan komputer diperoleh nilai Koefisien Reliabilitas Alpha Cronbach, sebagai berikut :

Tabel 5. Koefisien Reliabilitas

\begin{tabular}{|c|l|c|}
\hline No. & \multicolumn{1}{|c|}{ Variabel } & $\begin{array}{c}\text { Koefisien Reliabilitas } \\
\text { (Alpha) }\end{array}$ \\
\hline 1. & Kompetensi guru (X) & 0.737 \\
\hline 3. & Prestasi belajar siswa (Y) & 0.780 \\
\hline
\end{tabular}

Sumber : Data Olahan

Hasil Koefisien Reliabilitas (Alpha) yang tertera pada Tabel 4.5, dapat dikatakan bahwa instrumen yang digunakan andal, artinya suatu instrumen yang dapat dipercaya untuk digunakan sebagai alat pengumpul data atau mengukur obyek yang telah ditetapkan karena instrumen tersebut sudah tergolong baik dimana koefisien reliabilitas alpha > dari alpha correctit alpha item correlation.

\section{Uji Autokorelasi}

Untuk hubungan kompetensi guru (X) dengan prestasi belajar siswa (Y), dari hasil perhitungan komputer dengan program SPSS diperoleh nilai statistik Durbin Watson sebesar 2.410, sesuai dengan kriteria bahwa apabila Durbin Watson-nya adalah -2 sampai 2 tidak dijumpai adanya otokorelasi, maka dalam regresi ini otokorelasi tidak dijumpai. Untuk lebih jelasnya dapat dilihat pada tabel berikut ini :

Tabel 6. Model Summary ${ }^{\mathrm{b}}$

\begin{tabular}{|l|r|r|r|r|r|}
\hline Model & R & R Square & $\begin{array}{c}\text { Adjusted R } \\
\text { Square }\end{array}$ & $\begin{array}{l}\text { Std. Error of } \\
\text { the Estimate }\end{array}$ & $\begin{array}{c}\text { Durbin- } \\
\text { Watson }\end{array}$ \\
\hline 1 & $.790^{\mathrm{a}}$ & .624 & .605 & 3.72640 & 2.410 \\
\hline
\end{tabular}

Sumber : Data Olahan

\section{Analisis Korelasi}

1. Koefisien Korelasi Sederhana

Tabel 7. Koefisien Korelasi Sederhana

Correlations

\begin{tabular}{|ll|r|r|}
\hline & & \multicolumn{1}{|c|}{$\mathrm{Y}$} & \multicolumn{1}{|c|}{$\mathrm{X} 1$} \\
\hline Pearson Correlation & $\mathrm{Y}$ & 1,000 &, 788 \\
& $\mathrm{X} 1$ &, 788 & 1,000 \\
\hline Sig. (1-tailed) & $\mathrm{Y}$ & $\cdot$ &, 000 \\
& $\mathrm{X} 1$ &, 000 &. \\
\hline $\mathrm{N}$ & $\mathrm{Y}$ & 43 & 43 \\
& $\mathrm{X} 1$ & 43 & 43 \\
\hline
\end{tabular}

Sumber : Data olahan 
Research and Development Journal Of Education

Vol. 6 No. 1 Oktober 2019

Tabel 8. Pedoman Untuk Memberikan Interpretasi Koefisien Korelasi

\begin{tabular}{|c|c|}
\hline Interval Koefisien & Tingkat Hubungan \\
\hline $0,000-0,199$ & Sangat rendah \\
$0,200-0,399$ & Rendah \\
$0,400-0,599$ & Sedang \\
$0,600-0,799$ & Kuat \\
$0,800-1,000$ & Sangat kuat \\
\hline
\end{tabular}

Sumber : Sugiyono, $2002: 183$

Berdasarkan tabel di atas dapat disimpulkan bahwa :

a. Koefisien Korelasi antara kompetensi guru (X) dengan Prestasi belajar siswa (Y).

Hubungan antara X (kompetensi guru) dengan Y (prestasi belajar siswa) adalah sebesar 0,788 menunjukkan hubungannya positif yang berarti bahwa apabila kompetensi guru meningkat, maka prestasi belajar siswa juga meningkat atau sebaliknya. Selain itu hubungannya kuat karena lebih besar dari 0,5 artinya apabila terjadi perubahan pada X (kompetensi guru) maka akan segera merubah $\mathrm{Y}$ (prestasi belajar siswa).

Untuk mengetahui pengaruh variabel $\mathrm{X}$ terhadap variabel $\mathrm{Y}$, dapat digunakan analisis Koefisien Determinasi $(\mathrm{Kd})$ yaitu sebagai berikut :

$$
\begin{aligned}
\mathrm{Kd} & =\mathrm{r}^{2} \times 100 \% \\
& =(0,788)^{2} \times 100 \% \\
& =0,620 \times 100 \% \\
& =62 \%
\end{aligned}
$$

Sedangkan koefisien determinasinya $\left(\mathrm{r}^{2}\right)$ adalah 0,620 yang berarti prestasi belajar siswa $62 \%$ ditentukan oleh kompetensi guru dan sisanya dipengaruhi oleh faktor lain sebesar $38 \%$.

2. Koefisien Korelasi Berganda

Tabel 9. Koefisien Korelasi Berganda

\begin{tabular}{|l|r|r|r|r|r|}
\hline & $\mathrm{R}$ & R Square & $\begin{array}{l}\text { Adjusted } \\
\text { R Square }\end{array}$ & $\begin{array}{l}\text { Std. Error of the } \\
\text { Estimate }\end{array}$ \\
\hline Model & $.790^{2}$ & .624 & .605 & 3.72640 \\
\hline
\end{tabular}

Sumber : Data olahan

Berdasarkan tabel di atas, diketahui bahwa besarnya koefisien korelasi berganda antara kompetensi guru dengan prestasi belajar siswa adalah 0,790 , artinya keeratan hubungan antara kompetensi guru dengan prestasi belajar siswa 
Research and Development Journal Of Education

Vol. 6 No. 1 Oktober 2019

p-ISSN 2406-9744

e-ISSN 2657-1056

adalah sebesar 79\%, hubungan ini menunjukkan kuat karena berada di antara 0,600 - 0,799 yang berarti bahwa apabila kompetensi guru meningkat, maka prestasi belajar siswa juga meningkat atau sebaliknya.

Untuk mengetahui hubungan variabel $\mathrm{X}$ dengan variabel $\mathrm{Y}$, dapat digunakan analisis Koefisien Determinasi $(\mathrm{Kd})$ yaitu sebagai berikut :

$$
\begin{aligned}
\mathrm{Kd} & =\mathrm{r}^{2} \times 100 \% \\
& =(0,790)^{2} \times 100 \% \\
& =0,624 \times 100 \% \\
& =62,4 \%
\end{aligned}
$$

Sedangkan koefisien determinasinya $\left(\mathrm{r}^{2}\right)$ adalah 0,624 yang berarti prestasi belajar siswa 62,4 \% ditentukan oleh kompetensi guru dan sisanya dipengaruhi oleh faktor lain sebesar $37,6 \%$.

\section{$\underline{\text { Pengujian Hipotesis }}$}

Untuk mengetahui kebenaran dari perhitungan koefisien korelasi di atas, maka diperlukan pengujian hipotesis. Perumusan hipotesis yang akan diuji diberi simbol $\mathrm{H}_{0}$, sedangkan untuk hipotesis alternatif diberi simbol $\mathrm{H}_{\mathrm{a}}$. Perhitungan test observasi $\left(\mathrm{t}_{0}\right)$ dapat dicari dengan menggunakan rumus sebagai berikut :

$$
\mathbf{t}_{\text {hitung }}=\frac{\mathrm{r} \sqrt{\mathrm{n}-\mathrm{k}}}{\sqrt{1-(\mathrm{r})^{2}}}
$$

$\underline{\text { Pengujian Hipotesis t untuk Variabel Kompetensi guru (X) }}$

$$
\begin{aligned}
& t_{\text {hitung }}=\frac{r \sqrt{n-2}}{\sqrt{1-(r)^{2}}} \\
& \mathbf{t}_{\text {hitung }}=\frac{0,788 \cdot \sqrt{43-2}}{\sqrt{1-(0,788)^{2}}} \\
& \mathbf{t}_{\text {hitung }}=\frac{0,788 \cdot(6,403)}{\sqrt{0,38}} \\
& \mathbf{t}_{\text {hitung }}=\frac{5,045}{0,616} \\
& \mathbf{t}_{\text {hitung }}=\mathbf{8 , 1 8 9}
\end{aligned}
$$

t tabel dengan $\alpha 5 \%$ dengan $n=43$

t tabel $\alpha=1,684$ 


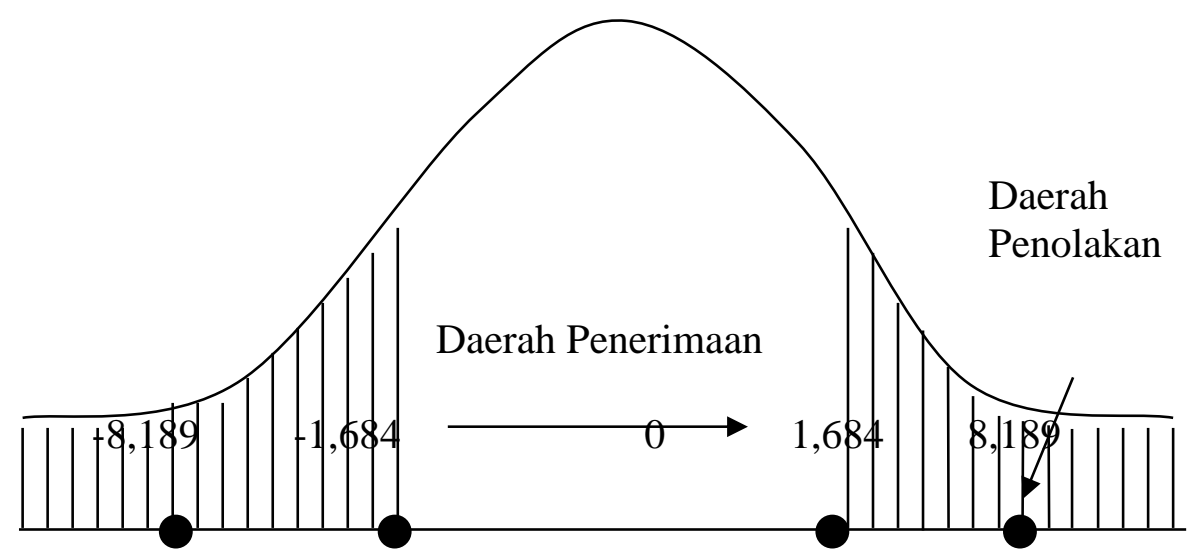

Gambar 3. Kurva Hipotesis Distribusi t untuk variabel Kompetensi guru (X)

Dari hasil perhitungan di atas diperoleh nilai $t_{\text {hitung }}$ sebesar 8,189, sedangkan $t_{\text {tabel }}$ dengan $\alpha=5 \%$ diperoleh $t_{\text {tabel }}$ sebesar 1,684. Dengan demikian $t_{\text {hitung }}(8,189)>$ $\mathrm{t}_{\text {tabel }}(1,684)$, maka Ho ditolak dan Ha diterima. Hal ini berarti bahwa terdapat hubungan yang signifikan antara kompetensi guru dengan prestasi belajar siswa pada mata pelajaran Bahasa Inggris di MI Miftahul Huda.

Pengujian Hipotesis t untuk Variabel Kompetensi guru $(\mathrm{X})$ dengan Prestasi belajar $\underline{\text { siswa }(Y)}$

$$
\begin{aligned}
\mathbf{t}_{\text {hitung }} & =\frac{r \sqrt{n-3}}{\sqrt{1-(r)^{2}}} \\
\mathbf{t}_{\text {hitung }} & =\frac{0,790 \cdot \sqrt{43-3}}{\sqrt{1-(0,790)^{2}}} \\
\mathbf{t}_{\text {hitung }} & =\frac{0,790 \cdot(6,403)}{\sqrt{0,376}} \\
\mathbf{t}_{\text {hitung }} & =\frac{5,058}{0,613} \quad \mathbf{t}_{\text {hitung }}=\mathbf{8 , 2 5 1}
\end{aligned}
$$

t tabel dengan $\alpha 5 \%$ dengan $n=43, t$ tabel $\alpha=1,684$

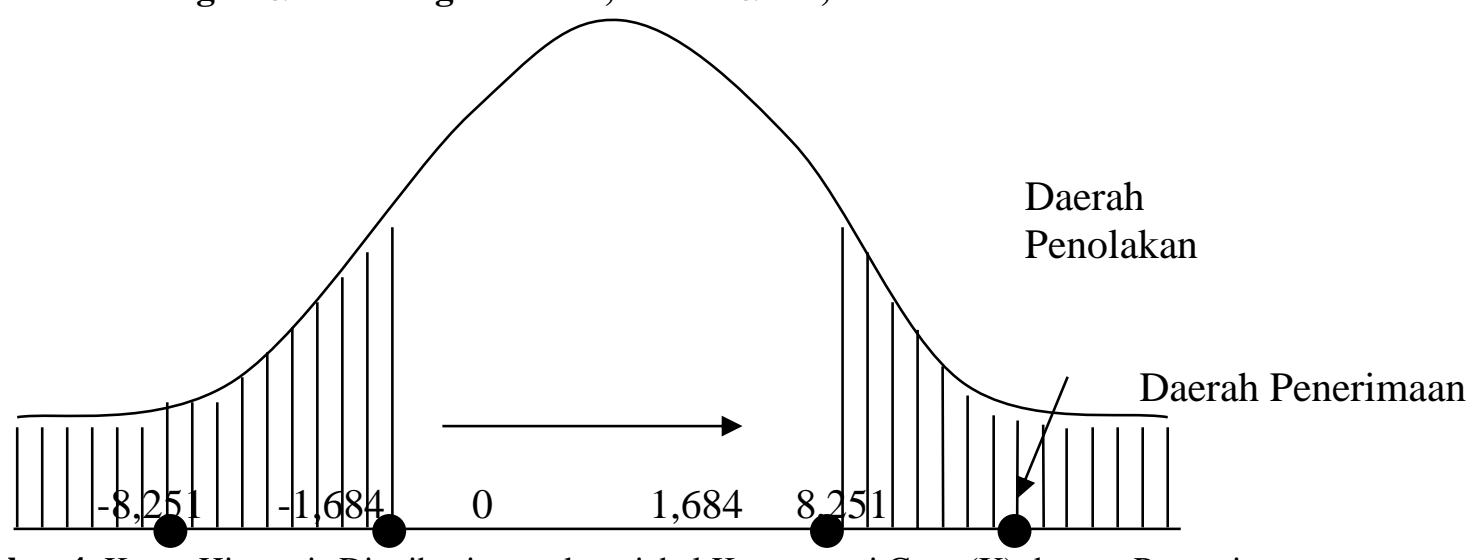

Gambar 4. Kurva Hipotesis Distribusi t untuk variabel Kompetensi Guru (X) dengan Prestasi Belajar Siswa (Y) 
Research and Development Journal Of Education

Vol. 6 No. 1 Oktober 2019

p-ISSN 2406-9744

e-ISSN 2657-1056

Dari hasil perhitungan di atas diperoleh nilai $t_{\text {hitung }}$ sebesar 8,251, sedangkan

$\mathrm{t}_{\text {tabel }}$ dengan $\alpha 5 \%$ diperoleh $\mathrm{t}_{\text {tabel }}$ sebesar 1,684. Dengan demikian $\mathrm{t}_{\text {hitung }}(8,251)$ $>t_{\text {tabel }}(1,684)$, maka Ho ditolak dan Ha diterima. Hal ini berarti bahwa terdapat hubungan yang signifikan antara kompetensi guru secara bersama-sama dengan Prestasi belajar siswa pada mata pelajaran Bahasa Inggris di MI Miftahul Huda.

\section{Pembahasan}

Berdasarkan hasil perhitungan diperoleh nilai $\mathrm{R}$ sebesar 0,790, oleh karena angka 0,790 berada pada interval 0,60 - 0,799 maka dapat dikatakan bahwa variabel independent yaitu kompetensi guru secara bersama-sama, memiliki hubungan yang positif dan sangat kuat dengah variabel dependentnya yaitu prestasi belajar siswa.

Untuk mengetahui berapa besar hubungan kompetensi guru dengan prestasi belajar siswa maka digunakan rumus koefisien determinasi :

$$
\begin{aligned}
\mathrm{KD} & =\mathrm{R}^{2} \text { X } 100 \% \\
& =(0,790)^{2} \times 100 \% \\
& =0,624 \times 100 \% \\
& =62,4 \%
\end{aligned}
$$

Dengan diperoleh koefisien determinasi $\left(\mathrm{R}^{2}\right)$ adalah 0,624 atau $62,4 \%$, maka dapat dikatakan bahwa kompetensi guru dengan prestasi belajar siswa adalah sebesar $62,4 \%$, sedangkan sisanya $37,6 \%$ dihubungani oleh faktor-faktor lain. Menurut analisis penulis bahwa hubungan antara kompetensi guru dengan prestasi belajar siswa pada mata pelajaran Bahasa Inggris di MI Miftahul Huda sangat signifikan, berdasarkan hal tersebut di atas bahwa kompetensi guru perlu dipertegas dan dioptimalkan dalam meningkatkan prestasi belajar siswa.

Dengan adanya kompetensi guru yang baik pada Adiharapkan dapat lebih meningkatkan prestasi belajar siswa. Jika keseluruhan faktor tersebut dianalisis secara mendalam, maka gambarannya adalah sebagai berikut:

1. Hubungan Kompetensi guru Dengan Prestasi belajar siswa.

Hasil penelitian menunjukkan bahwa terdapat hubungan positif kompetensi guru dengan prestasi belajar siswa pada mata pelajaran Bahasa Inggris di MI Miftahul Huda. Hal ini ditunjukkan dengan signifikansi koefisien $t_{\text {hitung }}$ sebesar 8,189 dengan nilai $\mathrm{t}_{\text {tabel }}(1.684)$ pada taraf signifikansi 0,05 . Hasil statistik tersebut menunjukkan bahwa kompetensi guru memberikan kontribusi yang signifikan 
Research and Development Journal Of Education

Vol. 6 No. 1 Oktober 2019

p-ISSN 2406-9744

e-ISSN 2657-1056

terhadap prestasi belajar siswa. Artinya makin baik kompetensi guru, maka akan semakin meningkat pula prestasi belajar siswa pada mata pelajaran Bahasa Inggris di MI Miftahul Huda.

2. Hubungan Kompetensi Guru Secara Bersama-Sama Dengan Prestasi Belajar Siswa.

Dari hasil perhitungan menunjukkan bahwa prestasi belajar siswa pada mata pelajaran Bahasa Inggris di MI Miftahul Huda dapat dipengaruhi oleh kompetensi guru secara bersama-sama dengan signifikansi $t_{\text {hitung }}$ sebesar 8,082. Dengan demikian $t_{\text {hitung }}(8,251)>t_{\text {tabel }}(1,684)$, maka Ho ditolak dan Ha diterima. Hal ini berarti bahwa terdapat hubungan yang signifikan antara kompetensi guru secara bersama-sama dengan prestasi belajar siswa pada mata pelajaran Bahasa Inggris di MI Miftahul Huda. Temuan tersebut menunjukkan bahwa terdapat hubungan positif dan signifikan kompetensi guru secara bersama-sama dengan prestasi belajar siswa pada mata pelajaran Bahasa Inggris di MI Miftahul Huda.

\section{PENUTUP}

Dari hasil penelitian diperoleh kesimpulan sebagai berikut :

1. Koefisien korelasi antara $\mathrm{X}$ (Kompetensi guru) dengan $\mathrm{Y}$ (prestasi belajar siswa pada mata pelajaran Bahasa Inggris) adalah sebesar 0,788 menunjukkan hubungannya positif yang berarti bahwa apabila Kompetensi guru meningkat, maka prestasi belajar siswa pada mata pelajaran Bahasa Inggris juga meningkat atau sebaliknya. Selain itu hubungannya juga kuat karena lebih besar dari 0,5 artinya apabila terjadi perubahan pada $\mathrm{X}$ (Kompetensi guru) maka akan segera merubah Y (prestasi belajar siswa pada mata pelajaran Bahasa Inggris). Dari diperoleh nilai $t_{\text {hitung }}(8,189)>t_{\text {tabel }}(1,684)$, maka Ho ditolak dan Hi diterima. Atau dengan kata lain bahwa terdapat hubungan yang signifikan antara Kompetensi guru dengan prestasi belajar siswa pada mata pelajaran Bahasa Inggris di MI Miftahul Huda.

2. Koefisien korelasi antara $X$ (Kompetensi guru) secara bersama-sama dengan Y (prestasi belajar siswa pada mata pelajaran Bahasa Inggris) adalah sebesar 0,790 menunjukkan hubungannya positif yang berarti bahwa apabila Kompetensi guru meningkat, maka prestasi belajar siswa pada mata pelajaran Bahasa Inggris juga meningkat atau sebaliknya. Selain itu hubungannya kuat 
Research and Development Journal Of Education

Vol. 6 No. 1 Oktober 2019

p-ISSN 2406-9744

e-ISSN 2657-1056

karena lebih besar dari 0,5, artinya apabila terjadi perubahan pada Kompetensi guru dan proses belajar siswa akan merubah prestasi belajar siswa pada mata pelajaran Bahasa Inggris. Dari hasil perhitungan diperoleh nilai $t_{\text {hitung }}(8,251)>t_{\text {tabel }}(1,684)$, maka Ho ditolak dan Hi diterima. Hal ini berarti bahwa terdapat hubungan yang signifikan antara Kompetensi guru secara bersama-sama dengan prestasi belajar siswa pada mata pelajaran Bahasa Inggris di MI Miftahul Huda.

3. Penelitian telah berupaya maksimal demi tercapainya penelitian ini, meskipun penelitian ini telah berhasil menguji hipotesis yang dianalisis namun disadari bahwa penelitian terbatas pada dua variabel bebas (kompetensi guru) dengan variabel terikat (prestasi belajar siswa) pada MI Miftahul Huda, sehingga tidak menutup kemungkinan diadakannya penelitian lanjut. Hal ini disebabkan masih banyak terdapat keterbatasan dalam kegiatan penelitian ini seperti, keterbatasan waktu dan tenaga dalam melakukan penelitian.

\section{DAFTAR PUSTAKA}

Anwar, M. (2018). Menjadi Guru Profesional. Prenada Media. Cetakan pertama. Hal. 16

Cut Fitriani, Murniati AR dan Nasir Usman (2017). Kompetensi Profesional Guru Dalam Pengelolaan Pembelajaran di MTS Muhammadiyah Banda Aceh. Jurnal Magister Administrasi Pendidikan Pascasarjana Universitas Syiah Kuala. Vol. 5 no. 2 Halm 88-95

Indah Susilowati, Himawan Arif Sutanto dan, Reni Daharti (2013) Strategi Peningkatan Kompetensi Guru Dengan Pendekatan Analysis Hierarchy Process. Journal of Economics and Policy, Volumen 6 no. 1 Hlm. 80-92

Sjafty Nursitti Maili dan Woro Hestiningsih (2016) Masalah-Masalah Pembelajaran Bahasa Inggris Pada Sekolah Dasar. Jurnal Media Penelitian Pendidikan. Vol. 11 no. 2 hal. 54-62

Sumar, W. T., \& Razak, I. A. (2016). Strategi pembelajaran dalam implementasi kurikulum berbasis soft skill. Deepublish. H. 131

Sugiyono, 2016, Metode Penelitian Kualtitatif, Kuantitatif dan Research And Development, Jakarta: Penerbit Alfabeta. 